\title{
Ministerstwo Nauki
}

i Szkolnictwa Wyższego

Digitalizacja archiwalnych numerów czasopisma naukowego Analecta Cracoviensia 1-24 (1969-1992) i ich publikacja w otwartym dostępie - zadanie finansowane w ramach umowy 672/P-DUN/2017 ze środków Ministra Nauki i Szkolnictwa Wyższego przeznaczonych na działalność upowszechniającą naukę

\section{ZAGADNIENIE POCZĄTKÓW MOWY LUDZKIEJ}

\author{
W s t ęp
}

Wszyscy badacze początków mowy ludzkiej twierdzą zgodnie, że mowa artykułowana stanowi specyficzną i najbardziej charakterystyczną cechę gatunku ludzkiego. Swiat człowieka, pisze biolog P. P. Grassé, jest światem słów, mowy artykulowanej, która jest wyłączną własnością człowieka ${ }^{1}$. Uzyskanie mowy artykułowanej było koniecznym uprzednim warunkiem dla swoistej kulturowej drogi człowieka. Mowa ludzka jest tworem ducha ludzkiego i dlatego niektórzy autorzy uważają, że pytanie o początek mowy ludzkiej jest równoznaczne $\mathrm{z}$ pytaniem o powstanie psychizmu ludzkiego ${ }^{2}$. Postęp w ludzkiej fazie ewolucji, objawiający się w kształtowaniu otoczenia, był dziełem grupy ludzkiej, która posiadła zdolność porozumiewania się, czyli przenoszenia od jednostki do jednostki informacji intelektualnej przez mowę ${ }^{3}$. Właśnie dla tej racji, pisze $\mathrm{P}$. Overhage, żadna $\mathrm{z}$ przyczynowych teorii hominizacji nie może zrezygnować $z$ prób rozwiązania tego zagadnienia ${ }^{4}$.

Początki tak ważnej dla człowieka funkcji, jaką jest mowa, giną w ciemnościach czasu, gdyż leżą w pomroce dziejów, która dzieli dzisiejszego człowieka od jego zwierzęcych przodków. Dlatego początki mowy artykułowanej są nam całkowicie nieznane i takie pozostaną ${ }^{5}$. Po-

1 Das Ich und die Logik der Natur, München 1973, 65.

$2 \mathrm{~K}$. Goerttler, Morphologische Sonderstellung des Menschen im Reich der Lebensformen auf der Erde, w: Neue Anthropologie, Bd II, Biologische Anthropologie, Zweiter Teil, Stuttgart 1972, 248.

3 C. Bresch, Zum Problem der Phasenwechsel der Evolution, w: Acta Teilhardiana, Jhg. XI (1974), 50.

${ }^{4}$ Die Evolution zum Menschen hin, w: Gott Mensch Universum, Graz-WienKöln 1974, 282.

5 G. Révész, Origine et préhistoire du langage, Paris 1950, 9; L. von Bertalanffy, Symbolismus und Anthropogenese, w: Handgebrauch und. Verständigung bei Affen und Frühmenschen, Bern-Stuttgart 1968, 139. 
wodem tego jest całkowity brak konkretnych świadectw, brak jakichkolwiek empirycznych dokumentów. Początki mowy ludzkiej pozostają do dziś zagadką, której nie można rozwiązać przez samo stawianie najbardziej przemyślnych hipotez. Najżywsza fantazja, pisze Grassé, nie może zastąpić bezpośrednich świadectw, które w tym przypadku są nieodwołalnie stracone. Właśnie dlatego biologowie okazują małe zaufanie nawet najnowszym teoriom początków mowy ludzkiej ${ }^{6}$. Zdaniem Overhage takie rezygnujące stanowisko jest zrozumiałe, gdy patrzymy na współczesne dyskusje naukowe, obfitujące w mnóstwo przemijających hipotez. Drugą przyczynę nierozwiązywainości tego zagadnienia przez naukę widzi Overhage $w$ niezmienialnym fakcie, że nie istnieje na ziemi taka istota, która dla swej inteligencji zajmowałaby stanowisko pośrednie pomiędzy szympansem i człowiekiem, przez co mogłaby dostarczyć empirycznego materiału dla rozwiązania tego żagadnienia ${ }^{7}$. Ponadto badań tych nie można przeprowadzać na szczątkach kostnych, pisze W. Stęślicka, a jedynie na aktualnie żyjących małpach i ludziach ${ }^{8}$.

Tak więc na początkach mowy ludzkiej położyły się „,białe plamy”, które kryją jej narodziny przed umysłem ludzkim. Jednakże pomimo tych pesymistycznych wypowiedzi badacze nie rezygnują z prób rozwiązania względnie przybliżenia się do rozwiązania tego zagadnienia. Angielski badacz zachowania się zwierząt W. H. Thorpe pisze, że wprawdzie nie mamy dzisiaj zupełnie zadowalającej teorii powstania mowy ludzkiej, jednak prawdopodobnie każda $\mathrm{z}$ nich zawiera $\mathrm{w}$ sobie coś prawdziwego ${ }^{9}$.

Co badacze rozumieją przez mowę? J. Illies zauważa, że potocznie mowę możemy rozumieć bardzo szeroko: zwierzęta mówią, ludzie mówią, fakty mówią, milczenie mówi itd. Jednakowoż we wszystkich tych wyrażeniach jest coś wspólnego, mianowicie chodzi o porozumiewanie się, o przekazywanie informacji. To najogólniejsze określenie mowy jako środka przekazywania informacji i porozumiewania się obejmuje także dźwiẹki nieartykułowane, gesty i inne znaki używane przez zwierzęta, co Illies uważa za słuszne, gdyż porozumiewanie się i przekaz informacji stanowi istotną część również zachowania się zwierzęcego ${ }^{10}$. Przy tej najogólniejszej opisowej definicji mowy pozostaniemy, aby precyzyjne określenie mowy ludzkiej nie wyznaczało z góry kierunku rozwiązania tego zagadnienia. Nie powinno się ustalać a priori, czym jest mowa ludzka i czym różni się od mowy zwierząt, ponieważ najnowsze badania nad zachowaniem się zwierząt wykazują nieznane dotąd akustyczne zdolności

6 Dz cyt., 67.

7 Art. cyt., 383.

s Ewolucja mowy $w$ filogenezie czlowieka, w: Studia Linguistica, I, Acta Universitatis Wratislaviensis No 197, Wrocław 1974, 54.

${ }^{9}$ Der Mensch in der Evolution, Müncben 1969, 128.

10 Zoologie des Menschen, München 1971, 100. 
zwierząt, co przesuwa granicę między mową ludzką i zwierzęcą, ustalaną kilkanaście lat temu. Bezpieczniejszą w tym względzie od drogi „od góry”, wychodzącej od definicji i uprzednich ustaleń, jest droga „od dołu", która wychodzi od empirycznego materiału.

Badacze mowy ludzkiej rczróżniają pomiędzy mową i językiem. Przez mowę rozumieją słowne wyrażanie psychicznych przeżyć, natomiast przez język zespół słów używanych w jednakowym znaczeniu i według stałych form gramatycznych ${ }^{11}$. Mówiąc o początkach mowy ludzkiej mamy na myśli nie już ukształtowane języki, lecz powstawanie pierwszych słów jako dźwięków artykułowanych, które służyły do wyrażania wewnętrznych stanów jedncstzi. Rozróżnia się trzy poziomy mowy: fonetyczny, gramatyczny i semantyczny. Jeżeli bierzemy pod uwagę powstanie mowy ludzkiej, to mówimy przede wszystkim o poziomie fonetycznym, a więc o tworzeniu fonemów i morfemów, czyli o artykulacji, której wytworem są jednostki głosowe tworzące, ,potok mowy”. Jeżeli jakaś osoba, piszą F. L. Ruch i P. G. Zimbardo, chce nauczyć się mowy, to musi nauczyć się rozróżniania i identyfikowania fonemów ${ }^{12}$.

Zagadnienie początków mowy ludzkiej można rozważać z różnych punktów widzenia, a więc filozoficznego, psychologicznego, lingwistycznego, społecznego, kulturowego itd.. Wydaje się jednak, że ujmowanie tego problemu z punktu widzenia jednej tylko dyscypliny naukowej, nie prowadzi do jego rozwiązania, gdyż wnosi tylko częściowe aspekty, które wcześniej czy później musi się złożyć w jedną organiczną całość. Problem początków mowy ludzkiej stanowi pytanie graniczne na styku wyżej wymienionych nauk. Nie jest to problem tylko filozoficzny, ponieważ mowa rozważana $z$ tego punktu widzenia dotyczy pytania, czym jest mowa w istocie człowieka, jak uczestniczy w jego życiu jako warunek, przyczyna i skutek ${ }^{13}$, natomiast pomija inne zagadnienia. Nie jest to problem tylko nauk szczegółowych, ponieważ w powstawaniu mowy ludzkiej bierze udział duchowa strona człowieka. Używając nazwy, którą wprowadził dlá innych celów G. H. Sitzmann ${ }^{14}$, można by powiedziec, że jest to problem należący do antropologii interdyscyplinarnej, w której wspólna refleksja filozoficzna łączyłaby ujęcia różnych nauk w jedną organiczną całość. Jednakże status takiej antropologii filozoficznej stanowi dzisiaj jeszcze zagadnienie otwarte.

11 A. Lalande, Vocabulaire technique et critique de la philosophie, ed. 8, Paris 1960,554 .

i2 Lehrbuch der Psychologie, Berlin-Heidelberg-New York 1974, 178.

1: Zob. L. Weisgerber, Die anthropologische Tragweite der energetischen sprachbetrachtung, w: Neue Anthropologie, Bd VII, Philosophische Anthropologie, Zweiter Teil, München 1974, 169; E. Coreth, Was ist der Mensch? Grundzüge einer philosophischen Anthropologie, Innsbruck-Wien-München 1973, $62 \mathrm{nn}$.

14 Interdisziplinäre Anthropologie zur neuen Wissenschaft Teilhards de Chardin, w: Acta Teilhardiana, Supplementa II, Evolutive Anthropologie, München 1971, $183-191$. 
Używając terminu „mowa”, będziemy mówić o mowie zewnętrznej, a pozostawimy całkowicie na uboczu problem mowy wewnętrznej, jej genezę i stosunek do mowy zewnętrznej ${ }^{15}$. Zagadnienie początków mowy zewnętrznej obejmuje dwa pytania. Pierwsze dotyczy problemu, w jaki sposób powstała mowa ludzka, jak człowiek przerobił przedsłowne tworzywo dźwiękowe w dźwięki artykułowane czyli słowa. Natomiast drugie dotyczy zagadnienia, kiedy w historycznym rozwoju człowieka czy istot przedludzkich, gdyż tego nie możemy wykluczyć a priori, powstały pierwsze słowa, pierwsze dźwięki artykułowane.

\section{JAK POWSTAEA MOWA LUDZKA}

Dwie postawy metodologiczne

W uwagach wstępnych wspomniano, że zagadnienie początków mowy ludzkiej można rozwiązywać idąc „od góry” lub „od dołu”. W stanowiskach tych przejawiają się dwie postawy metodologiczne badaczy: odrzucenie względnie przyjęcie ewolucyjnej ciągłości mowy zwierzęcej i ludzkiej. Pierwsza grupa badaczy zaprzecza tej ciągłości i uważa mowę artykułowaną za wyłączny twór człowieka, twór, który nie znajduje żadnych przedstadiów w mowie zwierzęcej. Do grupy tej należy cały szereg wybitnych autorów. I tak G. Révész uważa, że tzw. ekspresje witalne, objawiające się $w$ afektywnych dźwiękach i ruchach zwierząt, nie dały początku mowie artykułowanej, ponieważ służyły do innych celów i podlegały innym prawom ${ }^{16}$. Podobnie wyraża się A. Portmann, że słowna i gestowa mowa ludzka jest czymś zupełnie różnym od wszelkich zwierzęcych dźwięków, ponieważ zwierzęta nie posiadają możliwości użycia dowolnego słowa jako znaku ${ }^{17}$.

Inni autorzy $z$ tej grupy zwracają uwagę na udział ducha ludzkiego $\mathrm{w}$ powstawaniu mowy ludzkiej, czego brak jest u zwierząt. Overhage podkreśla, że symboliczna mowa ludzka nie rozwinęła się z mowy zwierzęcej, lecz powstała z duchowej struktury człowieka. Systemy porozumiewania się Prymatów nie stanowiły żadnego kroku w kierunku mowy ludzkiej. Mowa Prymatów wykazuje znacznie większą wspólnotę z mową innych zwierząt niż z ludzką. Podobieństwo widzi Overhage jedynie $\mathrm{w}$ sposobach wyrażania emocji i doznań przez gesty, mimikę i proste dźwięki u człowieka. Za G. Kelemanem Overhage przyjumuje, że wyimaginowana istota wyposażona $\mathrm{w}$ mózg człowieka i gardło szympansa, na podstawie samych anatomicznych danych, nie mogłaby wydawać żadnych

15 O mowie wewnętrznej zob. E. Grodziński, Mowa wewnętrzna, WrocławWarszawa-Kraków-Gdańsk 1976, 20-21.

$16 \mathrm{Dz}$ cyt., 92. $94,96$.

17 Biologische Fragmente zu einer Lehre vom Menschen, Basel-Stuttgart 1969, 
innych dźwięków niż to zwierzę, ponieważ do powstania mowy konieczną jest myśl ${ }^{18}$. Natomiast za F. J. J. Buytendijk pisze, że mowa ludzka nie posiada żadnego początku, lecz stanowi pra-skok podobny do mutacji. Można tylko badać warunki przygotowawcze i punkty oparcia dla tego skoku ${ }^{19}$.

Jeszcze radykalniej formułuje swój pogląd K. Goerttler, według którego nie ma żadnych prehistorycznych przedstadiów w mowie zwierzęcej dla duchowej struktury mowy ludzkiej. Ten fakt posiada według niego elementarne znaczenie dla badania powstania mowy ludzkiej, gdyż wyklucza z góry wszelkie próby wyjaśnienia tego problemu przez doświadczenia nad zwierzętami ${ }^{20}$. Goerttler przyznaje, że biologicznie nastawieni badacze, opierając się o założenia ewolucji, zakładają stopniowy rozwój mowy ludzkiej ze zwierzęcej, jednakże uważa, że to utożsamienie dźwięków zwierzęcych ze słowami nie rozwiązuje problemu a tylko go przykrywa ${ }^{21}$. Overhage i Goerttler zdają się podążać w tym względzie za myślą Buytendijka, który przyjmuje odwrotny niż ewolucjoniści kierunek badań sądząc, że dla zbadania języka zwierzęcego należy wyjść od języka ludzkiego, gdyż tylko w ten sposób można pojąć dźwięki wydawane przez zwierzęta ${ }^{22}$.

Druga grupa autorów sądzi wprost przeciwnie, że zgodnie z zasadami ewolucjonizmu istnieja jakieś przedstadia mowy ludzkiej w świecie zwierzęcym. Autorzy ci wcale nie utożsamiają mowy ludzkiej ze zwierzęca, inaczej tylko pojmują genezę mowy artykułowanej, gdyż nie odrzucają jej związków ze systemem porozumiewania się zwierząt. Przez jakiś czas, pisze Thorpe, wielkim powodzeniem cieszyła się teoria, że posiadanio mowy artykułłowanej stanowi podstawową różnicę między człowiekiem i zwierzęciem. Thorpe uważa, że dzisiaj nie możemy przyjąc tego twierdzenia jako zrozumiałego samo przez się, niezależnie od tego, czy jest ono słuszne, czy nie. Dla rekonstrukcji przebiegu ewolucji mowy w różnych fazach jej rozwoju od przodków przedludzkich musimy dzisiaj zwrócić uwagę na sposoby i środki porozumiewania się zwierząt 23 .

Podobnie wyraża się D. Katz, że mowa we właściwym tego słowa znaczeniu zachodzi tylko u człowieka, jednakże korzenie, przedstadia i pewne osiągnięcia $w$ tej dziedzinie mają miejsce także i u zwierząt. W psychologii zwykło się rozróżniać trzy funkcje mowy: funkcję wyrażania (funkcja ekspresyjna), funkcję wywoływania pożądanych reakcji

18 P. Overhage i K. Rahner, Das Problem ded Hominisation, Quaest. Disp. 12/13, Freiburg 1961, 298, 301.

${ }_{19}$ Das Problem der Hominisation, 285. W języku niemieckim zachodzi gra słów: Ursprung i Ur-Sprung.

20 Art. cyt., 248; Zob. P. Siwek, Ewolucjonizm $w$ świetle nauki, Londyn 1973,

173 nn.; Grodziński, dz. cyt., 18.

21 Art. cyt., 249.

22 F. J. J. Buytendijk, Traité de psychologie animale, Paris 1952, 221-222.

23 Dz. cyt., 119. 
(funkcja społeczna przekazu) i funkcję intencjonalną. W mowie zwierzęcej zachodza pierwsze dwie funkcje, natomiast brak jest funkcji intencjonalnej. Jest rzeczą ciekawą, pisze Katz, że dziecko ludzkie uczy się najpierw ekspresyjnej i przekazującej funkcji mowy i dopiero później zaczyna używać także funkcji intencjonalnej 24 .

W. C. Osman Hill uważa za niewątpliwe, że środki porozumiewania się używane przez Prymatów stanowią podstawę dla bardzo zróżnicowanych i złożonych procesów mowy u człowieka. Według niego można powiedzieć ogólnie, że człowiek przejął większą czę́ś dźwiękowego sposobu wyrażania się z przedludzkiego stopnia rozwoju mowy akustycznej zwierząt. Ta recepcja dotyczy nie tylko mowy małp człekokształtnych, lecz także mowy innych Prymatów, gdyż istnieje większe podobieństwo dźwięków wydawanych przez człowieka do dźwięków wydawanych przez Pawiany, niż do głosów szympansa ${ }^{25}$.

Jeszcze szerzej ujmuje rzecz D. Ploog, że do badania biologicznych fundamentów i założeń naturalnego rozwoju mowy ludzkiej nadają się wszystkie w społecznościach żyjące zwierzęta, a to zarówno ze względu na różnorodność form porozumiewania się, jak i ze względu na funkcje systemu nerwowego. Jego zdaniem otwiera się przez to droga do stworzenia ogólnej teorii komunikacji w biologicznych systemach. Całemu temu nowemu kierunkowi badań nadano ostatnio nazwę zoosemiotyki, w odróżnieniu od antroposemiotyki. Ploog przyznaje, że na razie jest spornym, czy odkryte $\mathrm{w}$ dziedzinie zoosemiotyki zasady porozumiewania się zwierząt stanowią konieczne uprzednie założenia dla powstania mowy ludzkiej, jednakże nie ulega wątpliwości, że zoosemiotyka wnosi istotne dane do awerbalnego sposobu porozumiewania się i do leżących u jego podstaw reguł dla antroposemiotyki. Zakładamy przy tym implicite, że porównania awerbalnego zwierzęcego i ludzkiego sposobu porozumiewania się można dokonać tylko w oparciu o teorię ewolucji i dane etologii. Genetycznie zawarunkowane podobieństwa między Prymatami i człowiekiem winny odpowiadać sobie zarówno w zakresie zachowania się, jak i porozumiewania się. Zdaniem Plooga wyniki eksperymentów z szympansicami Washoe i Sarah wykazują, że mowy ludzkiej nie można traktować jako izolowanego osiągnięcia i dlatego należy badać ją w jej psychobiologicznych związkach ${ }^{26}$.

J. Monod uważa za trudny do przyjęcia pogląd tych lingwistów, którzy uważają mowę ludzką za absolutnie niesprowadzalną do systemu

24 Handbuch der Psychologie", Basel-Stuttgart 1960, 263-264.

25 Verständigungsmittel bei Affen, w: Handgebrauch und Verständigung bei Af. fen und Frühmenschen, Bern-Stuttgart 1968, 51, 53.

26 Kommunikation in Affengesellschaften und deren Bedeutung für die Verständigungsweisen des Menschen, w: Neue Anthropologie, Bd II, Biologische Anthropologie, Zweiter Teil, Stuttgart 1972, 98-99, 169. 
porozumiewania się używanego przez zwierzęta. Hipotezę tę traktuje jako co najmniej bezużyteczną, gdyż nie można przyjąć założenia, że mowa ludzka nie wzięła niczego przy swym powstawaniu ze zwierzęcego systemu apelowania i ostrzegania. Mowa artykułowana, od chwili pojawienia się jej w linii ludzkiej, nie jest wytworem samej tylko ewolucji kulturowej, gdyż decydujące znaczenie miała także fizyczna ewolucja człowieka. Jeżeli tak było, pisze Monod, to zdolność mowy, która objawiła się epigenetycznie w procesie rozwoju mózgu, stanowi dziś część fizycznej „natury” czlowieka określonej w genomie, tylko w języku radykalnie różnym od zwykłego genetycznego kodu ${ }^{27}$.

Buytendijk zdaje się słusznie sugerować, że poglądy pierwszej grupy autorów posiadają swe źródło czy oparcie w nauce Kartezjusza o radykalnej różnicy pomiędzy człowiekiem i zwierzęciem, natomiast poglądy drugiej grupy wyrosły z nauki Darwina, który w dźwiękach zwierzęcych widział pożyteczne narzędzie $w$ walce o byt ${ }^{28}$. Wydaje się, że słuszną jest tendencja drugiej grupy autorów i zgodnie $z$ nimi badania nad początkiem mowy ludzkiej należy oprzeć o zasady ewolucjonizmu. Człowiek bowiem pojawił się na ziemi jako istota wyrosła ze zwierzęcych przodków, od których przejął całe wyposażenie w aparat dźwiękowy. Część tego zasobu dźwiękowego przerobił człowiek w mowę artykułowaną.

Tego rodzaju metodologiczne założenie nie uważa ludzkiej mowy za wyłączną przeróbkę i rozwój mowy zwierzęcej i nie ogranicza się do badania tylko ewolucyjnego przekazu mowy. Dla całkowitego i wszechstronnego zbadania problemu genezy mowy ludzkiej należy uwzględnić nie tylko założenia dziedziczne, lecz także wkład ducha ludzkiego, który do mowy ludzkiej wniósł $\mathrm{w}$ procesie ewolucji to, co nazywamy nowością ewolucyjną, ,ewolucyjnym czymś więcej” czy ,przekraczaniem siebie”. Jednakże przy rozważaniu początków mowy ludzkiej należy uważać za bezpieczniejszą drogę ,od dołu”. Od samego bowiem początku jest to droga kontrolowana i weryfikowana doświadczalnymi danymi. Nie znaczy to, że należy odrzucać czy pomniejszać znaczenie drogi „od góry”. Owszem, zgodność wyników obu dróg może stanowić dodatkowe kryterium słuszności kroków badawczych, przez co może doprowadzić szybciej do unitarnej teorii genezy mowy ludzkiej.

\section{Organiczne uwarunkowania mowy artykułowanej}

Według O. H. Schindewolf wstępną fazę ewolucji, umożliwiającą powstanie i rozwój mowy ludzkiej, stanowiło swobodne używanie ręki i zdobycie wyprostowanego chodu. Dzięki przejęciu przez ręce funkcji zdoby-

${ }_{27}$ Le hasard et la nécessité, Essai sur la philosophie naturelle de la biologie, Paris 1970, 144, 150-151.

28 Dz. cyt., $220-221$. 
wania pożywienia i walki, usta mogły formować dowolnie dźwięki ${ }^{29}$. Samo powstanie mowy było związane z rozwojem aparatu mowy, obejmującego krtań, język i wargi oraz z rozwojem kory mózgowej. Mowa artykułowana, pisze Grassé, zakładała skoordynowanie działania mięśni gardła, języka, policzków, których czynność musiała być zharmonizowana $z$ oddychaniem. Więcej jednak niż od anatomii organów głosowych zależy mowa od organizacji mózgowej ${ }^{30}$. Zmiany w filogenetycznym aparacie mowy przedstawia B. G. Campbell następująco: 1. Uformowanie się występu bródkowego, co dało większą ruchliwość językowi. 2. Pewne skrócenie i poszerzenie żuchwy spowodowało przesunięcie bardziej w tył podstawy języka, w okolice przełyku. 3. Nagłośnia została oddzielona od podniebienia miękkiego. 4. Mięśnie języka umożliwiły mu poruszanie się bardziej doskonałe. Wskutek tego mogła być całkowicie zamknięta jama nosowa, a powietrze mogło być wydawane tylko przez usta. Język i wargi mogły poruszać się dowolnie i dowolnie zatrzymywać pęd powietrza. Zdobycze te miały wielkie znaczenie, ponieważ dźwięki są wytwarzane w strunach głosowych i modulowane w ustach, przy czym język i wargi formułują samogłoski ${ }^{31}$.

Tak więc zdobycie wyprostowanego chodu miało wpływ na możliwość formowania dźwięków artykułowanych. Badania porównawcze wykazały, pisze Stęślicka, że osadzenie głowy na kręgosłupie spowodowało u człowieka powstanie specyficznych warunków dla przepływu powietrza przy wdechu i wydechu, innych niż u Prymatów. Ustawienie jamy ustnej i nosowej niemal pod kątem prostym względem gardła i krtani, oraz niskie położenie chrząstki nagłośniowej (epiglottis), zwiększyły u człowieka możliwości fonacyjne. Duża ruchliwość podniebienia miękkiego pozwoliła na łączenie jamy nosowej z jamą ustną, wskutek czego człowiek mógł swobodnie oddychać zarówno przez nos jak i usta, co w tym zakresie nie jest możliwe u żadnej małpy. Ruchome wargi, język i podniebienie miękkie, współdziałające z nieruchomymi dziąsłami, zębami i podniebieniem twardym, tworzyły charakterystyczne zwarcia i szczeliny, które zmieniały warunki w ustnym rezonatorze. Wskutek tego przepływający strumień powietrza ulegał rozczłonkowaniu, a to było podstawowym warunkiem artykulacji 32 .

Goerttler dodaje, że charakterystyczną dla człowieka jest właśnie piętrowa budowa aparatu gardłowo-ustnego. Tylko u człowieka istnieje pomiędzy jamą nosową i krtanią odcinek, w którym krzyżują się drogi powietrza i pokarmu. Jest to pewna niedogodność w stosunku do zwie-

${ }_{29}$ Phylogenie und Anthropologie aus paläontologischer Sicht, w: Neue Anthropologie, Bd I, Biologische Anthropologie, Erster Teil, Stuttgart 1972, 264.

30 Dz cyt., 68.

31 Entwicklung zum Menschen, Stuttgart 1972, 318-320.

32 Art. cyt., 54-55. 
rząt, gdyż tylko człowiek a nie zwierzę może się udławić, jednakże w stosunku do zwierzęcia człowiek zyskał przez to większe możliwości artykulacji. Ponadto tylko człowiek posiada wiązadła głosowe ${ }^{33}$.

Jest rzeczą charakterystyczną, że występ bródkowy nie występuje u najstarszych i współczesnych form Człowiekowatych (Hominidae). Okazało się jednak, że i u człowieka cecha ta występuje dopiero wraz z rozwojem osobniczym. Żuchwa niemowlęcia składa się początkowo z dwóch oddzielnych połówek, które dopiero później łączą się ze sobą poprzez klin kostny i tak powstaje występ bródkowy. Przyczepy mięśni w postaci tzw. kolców bródkowych posiadają również pewne znaczenie dla sprawności mówienia ${ }^{34}$. Illies zwraca uwagę na charakterystyczny moment, że możliwość mowy u dziecka ludzkiego zachodzi dopiero pod koniec pierwszego roku życia, po wykształceniu się jamy gardłowej i krtani. Przed ich wytworzeniem niemowlę nie może mówić, ale też $z$ tego samego powodu nie mogą mówić dzisiejsze małpy, ponieważ ich krtań pozostaje przez całe życie w stanie rozwoju, jaki ma miejsce u niemowlęcia ludzkiego. Illies sądzi, że właśnie dlatego zawodzą wszelkie próby uczenia małp mowy artykułowanej, chociaż pod względem inteligencji stoją na poziomie dwuletniego dziecka ${ }^{35}$.

Mowa artykułowana zależy więcej od organizacji mózgowej, niż od wykształcenia ludzkiego aparatu głosowego. Mowa bowiem, pisze Campbell, jest czymś więcej, niż złożonym dźwiękiem. Mowa jest kodowaniem myślenia w szereg kontrolowanych i powiązanych ze sobą dźwięków. Ta kodyfikacja ma miejsce $\mathrm{w}$ korze mózgowej ${ }^{36}$. Według Illiesa jest oczywistym, że rozwój mózgu stanowi uprzednie założenie do tego, by z naszych zwierzęcych praprzodków mógł powstać mówiący człowiek. Właśnie mózg rozwijał się niesłychanie szybko. Objętość mózgu wynosiła przed dwoma milionami lat $300-600 \mathrm{~cm}^{3} \mathrm{u}$ Australopithecinae, ok. 700 $\mathrm{u}$ formy Homo habilis, $800 \mathrm{u}$ Homo erectus z Oldoway, $900 \mathrm{u}$ Pithecnathropusa i $1300 \mathrm{~cm}^{3}$ u Człowieka ze Swanscombe. Normalne mechanizmy ewolucji, którymi są mutacja i selekcja, nie mogą same wytłumaczyć tak szybkiego rozwoju mózgu. Fachowcy elektronicy wyliczyli, pisze dalej Illies, że dla stworzenia prawdziwej mowy byłby potrzebny mózg o pojemności ok. $900 \mathrm{~cm}^{3}$. Z tego wynikałoby, że pierwotny Homo erectus $z$ Oldoway, Jawy i Pekinu posiadał wystarczająco rozwinięty mózg, aby mógł stworzyć mowę ${ }^{37}$.

Pierwszorzędne pole ruchowe mowy, kontrolujące ruchy warg, języka i krtani, leży w korze czołowej. Doświadczenia wykazały, że ośrodki

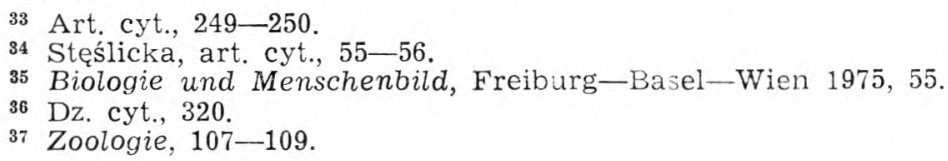


mowy u praworęcznych leżą najczęściej w lewej czyli dominującej półkuli mózgu. Również ośrodek ciemieniowo-skroniowy mowy, występujący tylko u człowieka, znajduje się w lewej półkuli. Odpowiadające mu pole prawej półkuli zarządza prawdopodobnie schematem ciała i stosunkami przestrzennymi. Sama dominacja lewej półkuli nad prawą jest zjawiskiem zachodzącym tylko u człowieka, a więc jest cechą specyficznie ludzką. Również interesującą rzeczą jest to, że cecha ta nie jest dana człowiekowi od urodzenia, lecz występuje wraz z rozwojem mowy, między 2 a 12 rokiem życia. Campbell uważa, że wszystkie powyżej przytoczone dane wskazują na to, że mowa jest genetycznie określoną cechą dzisiejszego człowieka. Ten godny uwagi i jedynie ludzki sposób zachowania się polega na szczególnym wyposażeniu genetycznym, co dało człowiekowi wielki wolno dojrzewający mózg i zdolność do tworzenia słów ${ }^{38}$.

H. Walter podaje, że ruchowy ośrodek mowy Broca, znajdujący się w trzecim dolnym zawoju czołowym, nie występuje u małp niższych, a u wyższych brak go tylko $u$ goryla. Ośrodek ten jest słabo zaznaczony u Orangutana, natomiast trochę silniej jest rozwinięty u szympansa. Tylna część tego zakrętu jest w pełni rozwinięta tylko u człowieka. W związku z tym tylko człowiek jest zdolny do mowy artykułowanej. Właśnie dlatego Walter uważa mowę artykułowaną za cechę specyficznie ludzką, a jej powstanie za ściśle związane $z$ hominizacją ${ }^{39}$.

Ploog zwraca uwagę na znaczenie badań z lat sześćdziesiątych, które wykazały, że ważną funkcję dla mowy pełnią areały podkorowe. Należą do nich wzgórze, system pozapiramidowy i śródmózgowie. Jego zdaniem nie ma obecnie wątpliwości, że obszary wzgórza i system pozapiramidowy posiadają rozstrzygające znaczenie dla wokalizacji, kontroli głosu i płynności mowy. Należy przyjąć, że te podkorowe struktury, jako filogenetycznie starsze, będą podobne u małp i ludzi. Wszystkie wokalizarje ssaków zdają się posiadać swoją matrycę w szarej jamie śródmózgowia. Badania te, pisze Ploog, będą miały duże znaczenie dla problematyki anatomiczno-mózgowych i filogenetycznych uprzednich warunków powstania mowy ludzkiej ${ }^{40}$.

Ruch i Zimbardo podkreślają znaczenie faktu, że zdolność mówienia stanowi wspólną gatunkową cechę ludzi. Nie ma znanej grupy ludzkiej bez mowy. Zdaje się to wskazywać, że pewne struktury mowy są wrodzone, co potwierdza fakt spontanicznego tworzenia reguł gramatycznych przez dzieci. Zdaniem tych autorów N. Chomsky i E. H. Lenneberg wykazali, że człowiek posiada wrodzone zdolności mowy ${ }^{41}$. Do tego samego

88 Dz. cyt., $321-323$.

39 Grundriss der Anthropologie, München-Basel-Wien 1970, 136.

40 Art. cyt., 144-145; Stęślicka, art. cyt., 58.

41 Dz. cyt., 108, 183-184; Ida Kurcz, Psycholingwistyka, Warszawa 1976, 208-211. 
wniosku, choć na innej drodze, dochodzi Illies. Rozróżnia aparat mowy i program mowy i uważa, że dużo zostało przekazane z zaprogramowania dziedzicznego. Formy możliwego doświadczenia, a więc schematy myślenia, sądzenia i logicznego wglądu stanowią uprzednie dane czynnościowe potencje mózgu. Jego zdaniem rozwiązuje się w ten sposób stary problem lingwistów, dlaczego ludzie posiadają wrodzone możliwości mowy i rozumienia mowy, oraz dlaczego posiadają tzw. rusztowanie ogólnoludzkiej gramatyki, które w procesie uczenia zostaje wypełnione wyrazami i formułami mowy. $\mathrm{Za}$ to rozstrzygające centrum uważa ośrodek mowy Broca ${ }^{42}$.

Monod, powołując się również na badania Chomsky'ego i jego szkoły, odrzuca ogólnie przyjęte twierdzenie, że mowa stanowi „superstrukturę", jako produkt drugiej ewolucji, czyli kultury. Trzeba według niego przyjąć, że między funkcją poznawczą i mową symboliczną istnieje u człowieka szeroka symbioza, będąca wynikiem długiej wspólnej ewolucji. Pozwala to przypuszczać, że od chwili pojawienia się w linii ludzkiej mowa nie jest wytworzona jedynie przez ewolucję kulturalną, lecz musi być przypisana w sposób decydujący fizycznej ewolucji człowieka ${ }^{43}$. Podobnie S. E. Luria twierdzi, że współczesna lingwistyka wykazała istnienie wspólnego gramatycznego modelu we wszystkich ludzkich językach, w czym wyraża się wspólna wszystkim ludziom organizacja mózgu. $\mathrm{W}$ procesie porozumiewania się mowa dlatego jest rozumiana przez drugich, ponieważ u wszystkich ludzi jest taka sama struktura mózgu. $\mathrm{Z}$ tego wynika, że mowa jest związana czę́sciowo z procesem uczenia się, a częściowo jest wyrazem struktury mózgu ${ }^{44}$.

Biorąc to wszystko pod uwagę dochodzimy do wniosku, że mowa ludzka, brana od strony organicznego uwarunkowania zdolności artykulacyjnych, nie pojawiła się u człowieka jako coś zupełnie nowego. Mowa bowiem posiada dziedziczne uwarunkowania w postaci rozwoju aparatu fonacyjnego i rozwoju pewnych struktur mózgowych, co stanowiło organiczne podłoże dla powstanie mowy artykułowanej. Nie należy jednak sprawy upraszczać i zapominać, na co słusznie zwraca uwagę A. Delmas, że sam rozwój aparatu mowy i ośrodków mowy w mózgu nie stanowi przyczyny sprawczej mowy ludzkiej, gdyż ta jest zjawiskiem psychicznym. Papuga potrafi prawidłowo artykułować słowa, lecz z tego nie wynika, że posiada zdolność mowy słownej ${ }^{45}$. Mowa artykułowana jest dziełem duchowej strony psychizmu ludzkiego. Nowe światło na problem początków mowy ludzkiej rzucają badania ostatniego dziesięciolecia nad mową zwierzęcą. Wykazują one, że zdolności psychiczne szympansów

42 Zoologie, $109-110$.

43 Dz. cyt., $150-151$.

44 Leben - das unvollendete Experiment, München 1974, 190.

45 Drogi $i$ ośrodki nerwowe, Warszawa 1975, 217. 
w tym względzie nie są tak małe, jak poprzednio sądzono i zagadnienie przedstadiów mowy ludzkiej u szympansów staje się coraz bardziej aktualne ${ }^{46}$.

\section{Próby odtworzenia początków mowy ludzkiej}

Można mówić o przyczynkach i całościowych hipotezach stawianych przez badaczy w celu rozwiązania zagadnienia początków mowy ludzkiej. Jedni autorzy rozwijają poszczególne myśli, drudzy konstruują obrazy hipotetycznego przebiegu procesu powstawania mowy. Zaczniemy od pierwszych. Campbell zwraca uwagę na pewną zbieżność społecznych warunków życia pawianów i pierwszych ludzi. Mianowicie pawiany zamieszkiwały, podobnie jak ludzie, równiny i prowadziły sposób życia zależny od struktury i współżycia grupy. Prawdopodobnie dlatego pawiany mogły wytworzyć przypadkowo samogłoski przez ruchy warg i języka, jako pomoc w porozumiewaniu się wewnątrz grupy ${ }^{47}$. Chcąc szukać początków mowy ludzkiej, należy według Campbella rozważać system komunikowania się, jaki rozwinął się w pierwotnym społeczeństwie ludzkim i umożliwiał porozumiewanie się $\mathrm{w}$ grupie. W szczególności należy rozważać sygnały wołania i odbioru, gdyż prawdopodobnie ten typ sygnałów rozwinął się w mowę, która umożliwiła człowiekowi osiągnięcie wszystkich zdobyczy kultury ${ }^{48}$.

Campbell przyznaje, że chociaż system okrzyków, nawoływań i mowa stanowią środki porozumiewania się, to jednak zachodzi pomiędzy nimi duża różnica i trudno prześledzić ewolucję od jednego do drugiego. Różnice te są następujące: 1. Okrzyki wykluczają się wzajemnie i stąd tylko jeden okrzyk może być wydany naraz. Tę sytuację określono jako „,zamkniętość” okrzyków. Natomiast mowa jest „otwarta”, tzn. możemy czynić dowolne kombinacje dźwięków. 2. Okrzyk jest wydawany tylko w obecności odpowiedniego bodźca, natomiast w mowie abstrahujemy od aktualnego bodźca, gdyż mówimy o rzeczach przeszłych i przyszłych, których aktualnie w ogóle nie ma. Ta zdolność mowy opiera się na procesach myślenia. 3. Różnica między dźwiękami okrzyków, nawoływań i mowy jest całkowita. Mowa stanowi rozszerzenie ograniczonej liczby dźwięków, które jako takie są bez znaczenia, lecz zgodnie z pewnym wzorem mogą posiadać nieograniczoną ilość znaczeń. 4. System okrzyków jest przypuszczalnie w wysokim stopniu wrodzony. Stosunek między bodźcem i reakcją jest genetycznie określony i stały, gdy mowa jest wyuczona i zakłada pamięć. Natomiast sama zdolność do mówienia stanowi wyposażenie dziedziczne ${ }^{49}$.

${ }^{46}$ Zagadnienie to poruszam na innym miejscu.

47 Dz. cyt., 320.

48 Tamże, 314.

49 Tamże, $316-317$. 
W podobnym kierunku idą rozważania Stęślickiej. Uważa ona mowę i myślenie za zjawiska społeczne, które w ogóle nie mogłyby się rozwinąć w samotności. Początki mowy ludzkiej wiąże z rozwojem kultur litycznych i dlatego według niej początków mowy należy poszukiwać równolegle $\mathrm{z}$ początkiem kultur. Pierwotny człowiek dysponował zapewne sporym repertuarem dźwięków, przy pomocy których mógł się porozumiewać. Niektóre z tych dźwięków stosował regularnie w określonych sytuacjach. W hordach wezesnoludzkich komunikacja ze współtowarzyszami odbywała się zapewne przy pomocy pomruków i krzyków, z którymi łączyły się gesty i mowa znaków. Instynktowne krzyki rozwijały się stopniowo poprzez coraz bardziej świadome i tradycją ustalone formy w swoiste wieloznaczne hasła i wyrazy, oznaczające skrót „zdania”. W dalszej ewolucji następowało zróżnicowanie składników prymitywnej mowy i zaczęły się rysować kontury rzeczywistej mowy. Bardzo pierwotny system krzyków i gestów trwał setki tysięcy lat i może rozpoczął się u schyłku trzeciorzędu u dwunożnych małp stepowych. Aż do społeczeństw neandertalskich włącznie prawdopodobnie nie wyszedł poza stadium izolowanych słów-pojęć, względnie najprostszych zdań dwuwyrazowych. Dopiero paleolit młodszy przyniósł zasadniczy zwrot przez rozwój kultury materialnej i duchowej. Pozwala to wnioskować o dynamicznym rozwoju mowy, która przed końcem paleolitu musiała być systemem w pełni ukształtowanym ${ }^{50}$.

Niektórzy autorzy zwracają uwagę na związek muzyki z mową. Stęślicka przytacza ciekawą hipotezę A. R. Darta o łączności muzyki z mową. Zdaniem Darta wczesne populacje ludzkie mogły stosować obok pierwotnej formy mowy także swego rodzaju instrumenty muzyczne. Nie ulega wątpliwości, że artykulacja posiada charakter rytmiczny i dlatego można dopatrywać się związków muzyki z mową. Najstarsze znane dotychczas instrumenty pochodzą z górnego paleolitu ${ }^{51}$. Nie jest to myśl nowa, gdyż znajdujemy ją już u Révésza, według którego awerbalne krzyki i wezwania zawierają istotne dla muzyki interwały, transpozycję oraz połączenia dźwięków. Dlatego można rozpatrywać muzykę jako pochodną krzyku. Natomiast wezwanie stanowi wspólny korzeń dla muzyki i mowy, ważną formę prelingwistycznego etapu ewolucji człowieka oraz punkt wyjścia dla mowy i muzyki 52 .

Inną ciekawą hipotezę wysuwa L. von Bertalanffy, według którego początki mowy ludzkiej mogły być połączone $z$ mitem i magicznymi praktykami. Prymitywny człowiek starał się ,opanować” swe otoczenie przez magię i czary, czyli przez manipulowanie wymyślonymi przez niego materialnymi lub akustycznymi zastępstwami rzeczy. Zdaniem Berta-

\footnotetext{
50 Art. cyt., 61, 69-70.

51 Art. cyt., 63 .

52 Dz. cyt., $172-174$.
} 
lanffiego daje to odpowiedź na pytanie, dlaczego antropoidy nie stworzyły mowy artykułowanej ${ }^{53}$. Pogląd ten fascynuje także Illiesa, który po przedstawieniu swej teorii o początkach mowy ludzkiej dodaje, że można snuć inne jeszcze przypuszczenia. U podłoża naszej mowy mogą leżeć czarodziejskie formuły zaklinania i magiczne słowa, które wypowiadał Adam jako szaman pierwszej grupy ludzkiej. Illies dodaje, że może to być najbardziej prawdopodobne przypuszczenie ${ }^{54}$.

Monod podchodzi zupełnie inaczej do zagadnienia początków mow y ludzkiej, upatrując właśnie w mowie czynnik hominizacji. Wychodząc z doświadczeń nad szympansami, które wprawdzie nie mogą mówić, lecz - mogą posługiwać się mową głuchoniemych przypuszcza, że zdobycie zdolności mowy artykułowanej i symbolizacji wcale nie postulowało zaistnienia u zwierząt bardzo skomplikowanych neuromotorycznych modyfikacji. Powstanie mowy stanowi ostatni produkt przypadku działającego w ewolucji. Wraz z dniem, pisze, w którym Zinjanthropus (Australopithecus boisei), lub któryś z jego towarzyszy użył po raz pierwszy artykułowanego dźwiękowego symbolu, ażeby przedstawić pojęcie, powstało prawdopodobieństwo wyłonienia się mózgu ludzkiego. Monod uważa za prawdopodobną hipotezę, że pierwsze symboliczne porozumienie się stanowiło jeden z początkowych przypadkowych wyborów, które dały początek nowemu gatunkowi przez stworzenie selekcji w tym kierunku. Ta selekcja faworyzowała rozwój osiągnięć lingwistycznych oraz rozwój ich organu czyli mózgu ${ }^{5}$.

Niektórzy autorzy zakładają odwrotnie, że myślenie pojęciowe stanowi uprzedni warunek dla powstania mowy. Thorpe pisze, że pierwsi ludzie musieli posiadać wpierw pojęcie, zanim mogli je wyrażać przez słowa ${ }^{56}$. Podobnie uważa Grassé, że mowa artykułowana zakłada zawsze uprzednie czynności intelektualne ${ }^{57}$. Nieco inaczej ujmuje to zagadnienie A. Remane, według którego najsilniejszym impulsem hominizacyjnym było wzrastanie zdolności do przypominania i rozpoznawania przeżytych treści. Zakres tej pamięci u zwierząt jest bardzo wąski i dlatego żyją one niejako w teraźniejszości. Natomiast ludzka pamięć sięga od pierwszych zapamiętanych przeżyć po teraźniejszość. Tę wielką kwantytatywną różnicę między zwierzęciem i człowiekiem uważa Remane za podstawę dla wytworzenia właściwej tylko człowiekowi mowy pojęciowej i całej duchowej kultury ${ }^{58}$.

as Art. cyt., $139-149$.

54 Biologie, 60-62.

5 Dz. cyt., $150-151,147-1 \leq 8$.

56 Dz. cyt., 134.

i7 Dz. cyt., 67.

Die Bedeutung der Evolutionslehre für die allgemeine Anthropologie, w: Nede Anthropologie, Bd I, Biolosische Anthropologie, Erster Teil, Stuttgart 1972, $321-322$. 
Przejdźmy teraz do przedstawienia niektórych barłziej rczwiniętych hipotez powstania mowy ludzkiej. Z polskich autorów A. Furdal podchodzi do tego zagadnienia $z$ punktu widzenia lingwistyki. W świecie istot żywych, pisze, spotykamy trzy rodzaje znaków: mowę, następnie sygnały jako znaki do przekazywania pewnych treściowo ograniczonych informacji zwanych komunikatami, oraz symptomy jako sygnały nieświadome, używane bez zamiaru informowania. Furdal stawia sobie pytanie, które z tych znaków mogły być używane w środowisku przedludzkim. Otóż u Antropoidów zachodzi posługiwanie się takimi sygnałami, jak krzyk i gest. Ze stanowiska lingwistyki nie można im odmówić wartości komunikatu. Nie mamy żadnych danych, pisze autor, że mowa ludzka rozwinęła się z innego źródła, niż sygnały nadawane i odbierane przez zwierzęta wyższe.

Centralnym punktem rozważań Furdala jest porównanie funkcji znaków dźwiękowych przedludzkich z ludzkimi. Sygnały przedludzkie spełniają funkcję wyłącznie komunikatywną. Za moment powstania mowy ludzkiej należy zatem uznać fazę wyodrębnienia się funkcji poznawczej w pierwotnych znakach dźwiękowych. Okrzyk posiada wartość komunikatu i jest jednorodny, tzn. przeciwstawia się innym okrzykom jako całość. W języku dzisiejszym akrzykowi odpowiadałoby zdanie. Natomiast funkcję poznawczą spełniają wyrazy, które symbolizują pewne elementy rzeczywistości w sposób abstrakcyjny, czyli w oderwaniu od konkretnej sytuacji. Stąd za najwcześniejszy moment powstania mowy ludzkiej uważa Furdal moment powstania wyrazu jako znaku symbolicznego, który nie jest nieodłącznie związany z funkcją komunikatywną.

Według Furdala zachodzą trzy możliwości powstania wyrazu z pierwotnego systemu sygnałów jako znaków komunikatywnych: 1. Komunikat jako całość przekształcił się w wyraz. 2. Komunikat rozpadł się na wyrazy. 3. Wyraz powstał z sumowania się komunikatów. Zdaniem autora szczególne znaczenie posiada możliwość druga, która polegała na wyodrębnieniu fraz dźwiękowych w komunikacie. To przejście do wyrazów i sam rozwój mowy trwały bardzo długo. Jednakże musiał kiedyś nastąpić czas, gdy wyodrębnione z komunikatów elementy dźwiękowe zaczęły spełniać funkcję poznawczą. I to, a nie co innego, uważa Furdal za początek mowy rozważany z punktu widzenia lingwistyki. Wyodrębnienie z komunikatów jednostek formalno-znaczeniowych mogło posłużyć w dalszym rozwoju mowy do stworzenia zupełnie nowych i dotąd nie uzywanych komunikatów i to Furdal uważa za foczątek produktywasci języka.

Miejscem spotkania się funkcji poznawczej z komunikatywną jest według autora definicja ostenzywna, np. ,, to jest las". Następna konstrukcja, np. ,sosna jest drzewem”, zwana zdaniem atomowym, stanowi 
wyższy krok poznawczy, ponieważ zezwala na budowę hierarchii pojęciowej. W komunikacie formowanym przy pomocy mowy wyróżnia Furdal trzy podstawowe treściowe kategorie: informację pozytywną, negację i pytanie. Pierwsza i podstawowa kategoria występuje w zwykłym komunikacie, np. ,droga jest wolna”. Kategoria ta jest obecna także w komunikatach zwierzęcych. Kategoria druga, negacja, jest konstrukcją typowo językową i jej wynalezienie uważa Furdal za chyba jeden z największych wynalazków w dziedzinie myśli ludzkiej. Trzecią kategorię, pytanie, w którym chodzi o rozstrzygnięcie „tak” lub „nie”, możemy określić jako komunikat równocześnie pozytywny i negatywny. Lecz z tego wynika, że pytanie rozważane jako kategoria myślowa, nie mogło powstać przed negacją. Dalsza rola pytania jest niesłychanie ważna, gdyż w pojęciowym ujmowaniu rzeczywistości stanowi naszą umiejętność stawiania pytań przy rozwiązywaniu problemów ${ }^{59}$.

Spośród różnych prób rozwiązania zagadnienia początków mowy ludzkiej wielkie uznanie zdobyła sobie teoria, którą postawił G. Révész. Dla wyjaśnienia początków mowy ludzkiej postawił teorię kontaktu. Przez kontakt rozumie relację między jednostkami tego samego lub różnych gatunków. Jest to relacja najpierw fizyczna, wynikająca z ogółu potrzeb fizycznych i jest przekazywana dziedzicznie. Zdaniem Révésza, chcąc odkryć historię powstania i rozwoju mowy, trzeba głębiej rozważyć potrzebę kontaktu fizycznego i przejść do kontaktu psychicznego, który może istnieć bez mowy i w rzeczywistości zachodzi także u zwierząt. Wprawdzie kontakt psychiczny nie stanowi uprzedniej formy mowy, jednakże mowa nie może istnieć bez kontaktu psychicznego. Ostatecznym celem wynikającym $\mathrm{z}$ potrzeby porozumiewania się jest kontakt myślowy, który jest ponadindywidualny i zbiorowy. Dopiero kontakt myślowy zakłada mowę artykułowaną, która powstała wtedy, gdy zostały zrealizowane uprzednie warunki kontaktu psychicznego i myślowego u członków pierwotnego społeczeństwa ludzkiego ${ }^{60}$.

Człowiek doszedł do wytworzenia rozwiniętęj mowy artykułowanej tylko przez rozwój systemu dźwiękowego. W systemie tym proste dźwięki nie posiadają jeszcze żadnego znaczenia komunikatywnego, są wydawane bez zamiaru porozumiewania się i nawiązania kontaktu. Takie dźwięki wydają także niemowlęta. Wyższą wartość posiadają zwierzęce dźwięki kontaktowe, które według Révésza stanowią przedfazę mowy i warunki przygotowawcze do mowy. Wśród dźwięków kontaktowych rozróżnia autor krzyk i wzywanie. Krzyk stanowi nieartykułowana emisja głosowa pochodzenia instynktownego skierowana do grupy. Wzywa-

${ }^{59}$ Czy językoznawstwo może zajmować się problemem pochodzenia języka? w: Studia linguistica I, Acta Universitatis Wratislavensis, No 197, Wrocław 1974, 92-97.

${ }^{60}$ Dz. cyt., $140-152$. 
nie różni się od krzyku tym, że jest skierowane do określonego osobnika, co wymaga jego obecności. Drugą cechą odróżniającą krzyk od wzywania jest rozkazujący charakter tego ostatniego. Ponadto krzyk i wzywanie różnią się genezą, ponieważ krzyk jest rządzony i kierowany instynktem, natomiast wzywanie rodzi się $\mathrm{z}$ indywidualnego doświadczenia ${ }^{61}$.

Krzyk i wzywanie nie stanowią hipotetycznych form pramowy, a jedynie reprezentują stałe formy porozumiewania się. Podobieństwo między wzywaniem i słowem istnieje tylko w zjawisku fonicznym. Wzywanie posiada charakter sygnału, natomiast słowo charakter symbolu. Symbol słowny zawiera związek formalny, ustalony między znakiem i rzeczą. Dźwięki naturalne mogą być przyjęte do słownika języka, lecz przez to tracą swój charakter czysto ekspresyjny, a nabywają znaczenia symbolicznego. W stosunku do słów sygnały są tylko awerbalnymi znakami potrzeby czy wzywania, bez wymiany myśli między nadawcą i odbiorcą ${ }^{62}$.

Awerbalne wzywanie mogło przerodzić się w słowo albo przez proces ciągły albo nieciągły. Révész opowiada się za ewolucją nieciągłą. Mowa nie powstała $z$ awerbalnego wzywania przez rozwój, ponieważ mowa ma swoją przyczynę powstania w twórczości człowieka. Człowiek chciał przekazać drugiemu człowiekowi swe potrzeby, życzenia i myśli. Posłużył się przy tym materiałem dźwiękowym w postaci wzywania, które było szczególnie przydatne do sformułowania pierwszych słów. Jest bardzo prawdopodobne, że na początku mieszały się ze sobą krzyk, wzywanie i prymitywne słowa. Najpierw przeważał krzyk, ustępując stopniowo miejsca słowu, natomiast wzywanie było nadal używane. Do słowa doprowadziło wzywanie, lecz nie możemy powiedzieć, jak dokonała się transformacja wzywania w słowo. W każdym razie symboliczna mowa wytrysnęła $z$ ducha ludzkiego, duch zrodził mowę i mowa jest funkcją myśli. Pojawienie się pierwszych słów wymagało mentalności nieporównywalnie wyższej od struktury psychicznej form przedludzkich ${ }^{63}$.

Po fazie przedhistorycznej, przygotowawczej do mowy i obejmującej dźwięki kontaktowe, nastąpiło według Révésza stadium mowy. W stadiunı mowy rozróżnia z kolei: 1 . fazę początkową, prahistoryczną, hipotetyczną pierwotną formę mowy, 2. fazę historyczną, w której rozróżnia podfazę mowy prymitywnej lecz charakteryzującej się już trzema funkcjami mowy: rozkazodawczą, oznajmiającą i pytaniową, oraz podfazę mowy rozwiniętej pod względem gramatyki i syntaktyki (języki ukształtowane) ${ }^{64}$.

Pierwotną fazę mowy stanowiła mowa rozkazująca. Instynktowna tendencja wyrażania swych stanów wewnętrznych przy pomocy dźwięków artykułowanych objawiła się najpierw w mowie o charakterze impera-

\footnotetext{
${ }^{61}$ Tamże, 153-165.

62 Tamże, 170.

63 Tamże, 175-183.

64 Tamże, 197-199.
} 
tywnym. Był to pierwszy etap mowy ludzkiej, jeszcze nierozwiniętej i niekompletnej. Révész nie twierdzi, że była to jedyna forma mowy, uważa tylko, że funkcja rozkazodawcza wzywania była dominująca. Składnikiem mowy archaicznej były prawdopodobnie formy wołania i życzenia. Funkcja rozkazująca istniała prawdopodobnie przed trybem oznajmiającym. Forma życzeniowa może być uważana za osłabienie mowy rozkazującej. Analogię widzi Révész u dziecka, które na początku nie posiada życzeń, a tylko wymaga spełnienia swych żądań ${ }^{65}$.

Awerbalne wzywanie (apel) uważa Révész za element łączący porozumiewanie się awerbalne ze słownym. Ze względu na to, że nie jest ono jeszcze słowem, należy do awerbalnych środków porozumiewania się, natomiast ze względu na swój charakter rozkazodawczy wiąże się bezpośrednio $z$ rozkazem słownym. Historia prawdziwej mowy rozpoczęła się wraz z ukazaniem się słowa. Według Révésza nie istnieje wspólna baza dla mówiącego zwierzęcia i człowieka. Nie można w ogóle mówić o mowie zwierząt, choć istnieje pewien związek między krzykiem czy wzywaniem zwierzęcym a językiem rozkazodawczym u ludzi. Zwierzęta mogą porozumiewać się i sygnalizować swe potrzeby fizyczne swym towarzyszom, jednak nie są to słowa, ponieważ nie służą do określenia przedmiotu. Dźwięki kontaktowe zwierząt służą jedynie do wyrażania ich afektywnych potrzeb i dążenia do ich zaspokojenia ${ }^{66}$.

Révész jest przekonany, że jego teoria kontaktu unika wszelkiej krytyki i daje podstawę dla rozwiązania zagadnienia początków mowy ludzkiej. Teorię swą uważa za pierwszą teorię lingwistyczną, która przekracza psychologię języka i wiąże się z danymi historii, przez co daje nowe podstawy dla psychologii lingwistycznej. Sądzi także, że jest to teoria wszechstronna, gdyż wyrosła w oparciu o dane psychologii zwierząt, psychologii dziecka oraz o dane lingwistyki ${ }^{67}$.

W poszukiwaniu odpowiedzi na pytanie, jak powstała mowa ludzka, Illies podąża za poglądami Révésza i G. Höpp'a. W odróżnieniu od Révésza wychodzi jednak $\mathrm{z}$ założeń teorii ewolucji. Zwierzęta, pisze Illies, posiadają system komunikacji, który nazwano dźwiękami odczucia emocjonalnego. Ten kontaktowy system dźwięków emocjonalnych pozostał całkowicie zachowany u człcwieka. Zachodzi tylko ta różnica, że dźwię̧ki te mogą otrzymać u człowieka znaczenie symboliczne, przez co stanowią „,przedsionek” mowy. Dźwięki te, jako nam wrodzone, należą do naszego biologicznego inwentarza zachowania się. Sama mowa, jako szczególna cecha człowieka, zakłada uprzednią strukturę duchową ${ }^{68}$.

\footnotetext{
(5) Tamże, $183-193$.

66 Tamże, 194, 211-215

i: Tamże, 202, 209, 222.

is Zologie, $102-104$.
} 
Wydawało się, że zagadnienie początków mowy ludzkiej zostało rozwiązane, gdy R. M. Yerkes i B. W. Learned (1925) ogłosili słownik mowy małp. Budując na tym słcwniku I. Schwidetzky uwierzyła, że będzie to linia rozwojowa, która łączy mowę szympansów poprzez pramongolską z indoeuropejską. Okazało się jednak, że szympansy nie mówią. Z twierdzenia tego prawdą okazało się tylko to, że istnieje zadziwiające podobieństwo dźwięków i znaczeń w językach różnych ludów, co wskazuje na wspólne korzenie mowy ${ }^{69}$. R. Fester próbował nawet ustalić te wyrazy, które można odnaleźć we wszystkich językach. Jego zdaniem wszystkie języki dadzą się sprowadzić do sześciu pratypów dźwięków artykułowanych: Ba, Kall, Tal, Os, Acq, Tag ${ }^{70}$. Illies nie sądzi, żeby próby te stanowiły odpowiedź na pytanie, jak powstała mowa ludzka. Nie wiemy bowiem, czy wymienione słowa mają stanowić tylko praelementy, rusztowanie mowy, czy można je wyprowadzić z budowy ludzkiej krtani, czy pierwszy człowiek bełkotał te słowa, czy wybrał je z małpiego zasobu dźwięków mlaskania i innych, czy też należy sprowadzić je do jednego pierwszego słowa. W odpowiedzi na te pytania jesteśmy zdaniem Illiesa skazani na czyste spekulacje, w rodzaju jakie czynił poeta Dante, według którego pierwszym słowem wypowiedzianym przez człowieka było słowo ,El" 71 .

Illies pragnie wyznaczyć drogę ewolucji, która doprowadziła do przemiany pewnej ilości znaków dźwiękowych w nową jakość symbolu, przez co z przekazu powstała mowa. Dla wyjaśnienia swej myśli używa Illies przykładu komputera, ze względu na jego podobieństwo do naszego mózgu. Podobnie jak w komputerzé mamy narzucone w pewnym zakresie przymusowe założenia techniczne, tak w naszym mózgu są dane optymalne drogi uprzywilejowane i wymuszone przez ewolucję. Technicy mówią o twardej (hard-ware) i miękkiej (soft-ware) strukturze komputerów, czyli o aparacie i programie. Z dobrym programem słaba maszyna może więcej zdziałać niż duża ze złym programem.

Zachodzi pytanie, pisze Illies, czy w zagadnieniu początków mowy ludzkiej chodzi o aparat czy o program. Wiadomo, że dla programu o pewnej złożoności konieczny jest dostatecznie rozwinięty aparat. Ponieważ nasza mowa posiada program o zaledwie wyobrażalnej złożoności, przeto w przebiegu ewolucji musiał najpierw powstać dostatecznie rozwinięty aparat, czyli nerwowa struktura mózgu. Rozwój mózgu był przeto uprzednim założeniem, żeby z naszych zwierzęcych przodków mógł powstać mówiący człowiek. Mózg naszych zwierzęcych przodków rozwinął się do tego stopnia, że wytworzył program przekazywania informacji. By

\footnotetext{
63 Biologie, $54-55$.

70 Zcolcoie, 114.

it Biologie, 55.
} 
mogła powstać mowa ludzka, zdolność komórek nerwowych przedniego mózgu musiała rozwinąć się do tego stopnia, żeby ponad programem wysyłania i przyjmowania informacji, sygnałów i znaków, mógł się rozwinąc program dla tworzenia pojęć. $\mathrm{Z}$ kolei dla wyrażenia tych pojęć szukał człowiek adekwatnych środków, znalazł je w słowach i dlatego uformował mowę ${ }^{72}$.

Po tych ogólnych rozważaniach i założeniach przechodzi Illies do bardziej szczegółowego przedstawienia swej teorii początków mowy ludzkiej. A mianowicie pyta o dane, które mogłyby wypełnić treścią taki program i doprowadzić do powstania słów. Révész zakładał u początzów mowy ludzkiej rozkazodawcze wzywanie, jako pierwotny stan jednosłownej mowy (przykłady takiej mowy posiadamy i dziś w takich wyrażeniach, jak ,stój”, „chodź”, ,idź” itp.). Illies modyfikuje ten pogląd w ten sposób, że wprawdzie zakłada na początku również słowo, jednak pojmuje je nie jako rozkaz, lecz jako jedno-powiedzenie (Einerspruch). Uważa bowiem, że słowo jest późniejszym, gramatycznym pojęciem, które nie mogło mieć zastosowania u zarania mowy ${ }^{73}$.

Teorię Révésza o rozkazodawczym wzywaniu rozszerzył już wcześniej G. Höpp w ten sposób, że wprowadził drugi rodzaj powiedzenia jednosłownego, którym jest imię własne. Miało ono zadanie ograniczać rozkaz, gdy ten dotyczył nie grupy, lecz jednego członka grupy. Imieniem własnym stawał się np. jeden stały określony dźwięk, którym matka wołała dziecko wtedy, gdy cała grupa zaczęła używać tego słowa na określenie dziecka. Höpp upatrywał w rozkazach i imionach własnych pierwotny stan ludzkiej gramatyki, z której miałả rozwinąc się cała nasza mowa. Dokonywało się to $\mathrm{w}$ ten sposób, że $\mathrm{w}$ dalszym rozwoju te dwie formy słów zostały połączone $\mathrm{w}$ powiedzenia dwusłowne, czyli w adresowany rozkaz. Lecz przez to została zdaniem Höppa otwarta droga do takiego przekształcenia pierwotnego przekazu, żeby mógł pełnić funkcję już nie rozkazu, lecz informacji o przeszłości, przekazywanej przez tradycję. Höpp daje taki przykład: Przywódca grupy każe X-owi robić siekierę, zaś Y-owi ściąć drzewo. Jest to forma rozkazu, lecz jeśli przywódca zwróci się do X-ksa z powiedzeniem: „Y-on ściąć drzewo”, to dla X-ksa będzie to stanowić nie rozkaz lecz informację, czy wiadomość. Illies sądzi, że Höpp przez swą oryginalną teorię przemiany rozkazu w wiadomość wniósł nowy przyczynek do zagadnienia początków mowy ludzkiej ${ }^{74}$.

Z kolei Illies wnosi poprawki do teorii Höppa o powstaniu i znaczeniu imion własnych. Höpp sądził, że bez nich nie może istnieć grupowe dzia-

i2 Zoologie, 105-108.

73 Biolocie, 57.

i4 Biologie, 58-59. 
łanie. Natomiast Illies uważa, że $\mathrm{z}$ obserwacji matek bawiących się z dziećmi można wyciągnąć zupełnie inny wniosek. Matka bowiem może porozumieć się $z$ dzieckiem bez użycia imiona własnego. Także dziecko zwraca się do matki słowem „mama”, które nie jest imieniem własnym i osiąga zamierzony cel, ponieważ matka rozpoznaje je po głosie. Podobnie zwierzę reaguje nie dlatego, że pan wymienia jego imię, lecz dlatego, że rozpoznaje swego pana po głosie. Illies wyprowadza stąd wniosek, że imię własne wcale nie stanowi koniecznego założenia dla adresowanego rozkazu, gdyż członek grupy może być określony i osiągnięty przez inne słowa niż imię własne. Potwierdza to fakt, że także dzisiaj nie zawsze używa się imion własnych, lecz takich słów, jak np. „ty tam” itp. Jednostka jest mniej lub więcej bezbarwna w grupie. Dopiero gdy sprzeciwi się przywódcy, staje się przeciwnikiem, a przez to ,osobą", do któreł trzeba się zwracać bezpośrednio. Potwierdzają to także przykłady z dziejów kultury. U prymitywnych szczepów indiańskich członkowie grupy nie posiadają od urodzenia imienia własnego, lecz je dopiero zdobywają poprzez próbę odwagi czy bohaterski czyn. Imię własne jest znakiem siły i rangi $\mathrm{w}$ grupie, a równocześnie przedmiotem magicznej rozporządzalności. Dlatego imię stanowi tabu u niektórych pierwotnych ludów.

Tak więc Illies akceptuje samą koncepcję dwusłownej wypowiedzi Höppa, która przez przeadresowanie staje się wiadomością, lecz w miejsce imienia własnego podstawia ogólne ,adresy”, mianowicie pojęcia klasy (mężczyzna, kobieta, siostra, brat, dziecko), określenia społecznej roli w grupie (ojciec, matka, król, wróg), skierowane rozkazy (ty, on), a w końcu szczególnie ważne słowo „,ja”. Prymitywna dwu-wypowiedź (Zweierspruch) przyjmowała przeto prawdopodobnie inne brzmienie. Przywódzca praludzkiej grupy mógł zwracać się do jednostek grupy słowami: „mężczyzna-robić-siekiera”, „ty-ściąć-drzewo" 75.

Illies zdaje sobie sprawę $\mathrm{z}$ tego, że wszelkie próby odtwarzania początkowej mowy ludzkiej są problematyczne. Zachodzi nawet pytanie, czy w ogóle mamy prawo stosowania do pramowy naszych dzisiejszych gramatycznych pojęć. Zastrzeżenie to zdaje się potwierdzać odkryte prawo względności mowy. Badając dialekty północnych Indian, Benjamin Lee Whorf odkrył, że Szawnisi nie znają czasowników i w swoisty sposób przekładają swe pojęcia w mowę. Np. zdanie: „pada deszcz” przybiera u nich formę: ,,stan pięknej pogody poza”. Szawnisi myślą bez czasowników i ich świat mowy wygląda trochę inaczej niż nasz. Gdybyśmy chcieli odtworzyć początki mowy ludzkiej, to musielibyśmy wiedzieć, pisze Illies, co myślał i czuł Adam. On i jego grupa mogli działac i porozumiewać się na długo przedtem, zanim powstała mowa. Mowa stała się dla grupy ludzkiej nowym energetycznym narzędziem, rozwijając się od jedno-po-

\footnotetext{
7.) Biologie, 59-60.
} 
wiedzeń do dwu-powiedzeń, $z$ rozkazu do wiadomości. To wszystko działo się w grupach, których członkowie stali w psychicznym kontakcie, a może i w telepatycznej łączności. Dla codziennego przekazu wystarczały gesty, spojrzenia i nieartykułowane dźwięki, którymi posługiwali się nasi zwierzęcy przodkowie. Te „biologiczne radykały” występują i dzisiaj. Dopiero wychodzące poza codzienność duchowe potrzeby sprawiły, że te biologiczne radykały nie mogły wystarczyć wczesno-ludzkim grupom i konieczną stała się mowa artykułowana. Można zresztą zdaniem Illiesa snuć inne jeszcze przypuszczenia na temat początku naszej mowy. Możliwa jest i taka alternatywa, że u podłoża ludzkiej mowy legły czarodziejskie formuły zaklinania i magiczne słowa, które wypowiadał Adam jako szaman grupy ${ }^{76}$.

\section{CZAS POWSTANIA MOWY LUDZKIEJ}

Równie trudnym do rozwiązania, jak zagadnienie początków mowy ludzkiej, jest problem czasu jej powstania. „Białe plamy” położyły się także i na tym zagadnieniu. Dlatego też autorzy stawiają tylko mniej lub więcej prawdopodobne hipotezy. Illies streszcza to zagadnienie w pytaniu: czy Adam w ogóle mówił i jak mówił. Jednak na tak postawione pytanie nie możemy jego zdaniem dać odpowiedzi przede wszystkim dlatego, że nie wiemy, kim był Adam i kiedy powstał. Dla biologa Adam stanowi symbol stawania się lud̄́mi naszych przedludzkich przodków, co miało miejsce przed paru milionami lat w tzw. „polu przejścia od zwierzęcia do człowieka", czyli w polu hominizacji. Z tego powodu nie można się dziwić, że poszukuje się początku mowy artykułowanej u naszych zwierzęcych przodków. Mowa ludzka musiała mieć kiedyś początek, swój punkt zerowy. Jeżeli wszystkie rasy ludzkie sprowadzamy do wspólnego początku, a w to nie wątpi dziś żaden biolog, to również wszystkie języki winny dać się sprowadzić do jednej pramowy i z niej się wywodzić. Dla dzisiejszego biologa byłoby niezrozumiałym, żeby tak istotna cecha gatunku Homo sapiens jak mowa, mogła powstać polifiletycznie, czyli wielokrotnie i niezależnie od siebie. Dowodem tego jest takie samo działanie centrum mowy w ludzkim mózgu ${ }^{77}$.

Schindewolf przesuwa najdalej w czasie początki mowy artykułowanej do przedludzkich Hominidów. Wprawdzie nie mamy żadnych danych, pisze, o zdolnościach mowy i abstrakcyjnego myślenia u form kopalnych, jednakże należy przypuścić, że mowa nie mogła powstać nagle w dzisiejszej formie w oderwaniu od mowy zwierzęcych przodków. U najstarszych Hominidów można rozpoznać na wewnętrznej stronie dolnej żuchwy garb kostny (Spina mentalis), służący do zaczepu pewnych mięśni języka, któ-

76 Biologie, $60-62$.

77 Biologie, 53-55. 
re są konieczne do wypowiadania dźwięków artykułowanych. $\mathrm{Na}$ tej podstawie Schindewolf przypuszcza, że już u tych form mogły zaistnieć początki porozumiewania się przy pomocy mowy i abstrakcyjnego myślenia ${ }^{78}$.

Walter uważa, żẻ przy końcu paleolitu został osiągnięty względnie wysoki stopień rozwoju technicznego, z czym wiąże się lepsze opanowanie środowiska i rozwój kultury. W tym czasie powstają rzeźby i pierwsze zaczątki magiczno-religijnych przedstawień. Te zróżnicowane osiągnięcia kulturalne czynią w wysokim stopniu prawdopodobnym, że paleolityczne formy ludzkie, łącznie z Neandertalczykiem, posiadały mowę. Zgodnie z opinią Schwidetzkiej Walter przypuszcza, że mowa musiała być wynaleziona najpóźniej przez formę Archanthropinae (Homo erectus). Jest również możliwym, że utrwalanie określonych dźwięków z określonym znaczeniem zaczęło się już u Australopiteków w postaci jednowyrazowych zdań. Mogły to być okrzyki i wzywania podobne do tych, jakimi dziecko rozpoczyna właściwą mowę ${ }^{79}$.

$\mathrm{Za}$ wieloma innymi autorami skłania się do tego poglądu u nas ks. Franciszek Rosiński. Sądzi, że nie powinno być zasadniczych zastrzeżeń natury morfologicznej i archeologicznej przeciw przyjęciu bardzo prymitywnej mowy artykułowanej u praczłowieka. Natomiast dyskusyjnym jest problem, czy początki słownego porozumiewania się można przesunąć do formy Australopithecinae. Wziąwszy pod uwage obecne doświadczenia nad mową szympansów, zwłaszcza przeprowadzone przez D. Premacka oraz R. A. i B. T. Gardnerów, autor skłania się do wniosku, że więcej racji przemawia za przyjęciem takiej możliwości niż za jej odrzuceniem ${ }^{80}$.

Wielu autorów wiąże początek mowy ludzkiej z rozwojem kultury. Według Révésza nie możemy odpowiedzieć na pytanie, czy pierwszy człowiek mówił, czy nie, jest jednak bardzo prawdopodobne, że człowiek paleolitu posiadał mowę w zasadzie podobną do naszej. Révész wyklucza hipotezę człowieka niemego (Homo alalus), jaki miałby istnieć na począiku. Jego zdaniem współpraca przy ogniu, wytwarzanie narzędzi, zbiorowa obrona, polowanie i przekazywanie doświadczeń, są niewyobrażalne bez mowy słownej. Człowiek jest tak samo z natury mówiący, jak jest z natury myślący. Język bowiem jest tworem ducha ludzkiego i nie było w historii ludzkości okresu bez mowy. Jeżeli Pithecanthropus mówił, to był człowiekiem, a jeżeli nie mówił, to był małpą ${ }^{81}$.

$\mathrm{Ku}$ temu ostatniemu stwierdzeniu Révésza skłania się K. J. Narr, który również sądzi, że byłoby trudnym wyobrazić sobie społeczeństwo

78 Art. cyt., 289.

79 Dz. cyt., 173.

80 Problem mowy artykutowanej we wczesnych stadiach hominizacji, w: $\mathrm{Z}$ zagadnień filizofii przyrodoznawstwa i filozofii przyrody, T. I, Warszawa 1976, $182-183$.

81 Dz. cyt., $99-100,212-213$. 
ludzkie funkcjonujące bez mowy. Prehistoria, dyscyplina którą się autor zajmuje, może jego zdaniem dorzucić do pytania o czas powstania mowy ludzkiej tylko tyle, że zdolności do prawdziwej mowy i myślenia abstrakcyjnego należy przyznać najwcześniejszym znanym wytwórcom narzędzi. Używanie narzędzi wskazuje na istnienie tradycji, wspólne działanie z planowaniem i porządkowaniem, a to wszystko byłoby zaledwie możliwe bez mowy słownej ${ }^{82}$.

Również Stęślicka wiąże powstanie mowy artykułowanej z rozwojem przemysłu litycznego. Zarówno mowa jak i myślenie są według niej zjawiskami społecznymi, które nie mogły rozwijać się w samotności. Autorka sądzi, że bardzo pierwotny system krzyków i gestów trwał setki tysięcy lat i może rozpoczął się u schyłku trzeciorzędu u dwunożnycir stepowych małp. Postęp w rozwoju tej mowy był podobny do rozwoju kultury. Wydaje się, pisze Stęślicka, że rozwój mowy aż do społeczeństw preneandertalskich włącznie nie wyszedł poza stadium izolowanych słów-pojęć, ewentualnie najprostszych zdań dwuwyrazowych. Zasadniczy zwrot nastąpił w paleolicie młodszym przez rozwój materialnej i duchowej kultury. Pozwala to zdaniem autorki wnioskować o dynamicznym rozwoju mowy, która pod koniec paleolitu musiała już być systemem w pełni ukształconym. Nie można podać czasowych początków mowy, ponieważ trudności powstają także przy próbach ustalenia początku prakultur ${ }^{83}$.

Poszczególni autorzy sądzą, że Neandertalczycy nie posiadali rozwiniętej mowy. R. A. S. Piaget uważa, że dopóki trwały tłuki pięściowe jako dominujący element kultury materialnej, tak długo istniała „zgeneralizowana pantomima z towarzyszącym bełkotem", co dotyczy także Neandertalczyków ${ }^{84}$. Podobnie M. A. Liebermann wystąpił $z$ twierdzeniem, że Neandertalczyk, analogicznie jak szympans, nie posiadał jamy krtaniowej, wskutek czego nie mógł wymawiać samogłosek ,a”, „u” oraz „,i”. Jego mowa musiała być bezbarwna, głucha i wzbogacona w dźwięki mlaskania i szeleszczenia, które spotykamy jeszcze u dzisiejszych Buszmenów ${ }^{85}$. Zarówno Stęślicka jak i Illies, za którymi przytaczam te poglądy, nie uważają ich za słuszne i tak zresztą uważa ogół autorów.

\section{WNIOSKI}

$\mathrm{Z}$ podanego szkicowego przeglądu wypowiedzi niektórych tylko autorów płynie wniosek, że zagadnienie początków mowy ludzkiej nie docze'kało się jeszcze pełnego rozwiązania ani co do pytania ,,jak”, ani co do

82 Beiträge der Urgeschichte zur Kenntnis der Menschennatur, w: Neue Anthropologie, Bd IV, Kulturanthropologie, Stuttgart 1973, 29-30.

83 Art. cyt., 58-59, 69-70.

84 Stęślicka, art. cyt., 61.

85 Illies, Biologie, 56. 
pytania „kiedy” i ciągle obracamy się w sferze mniej lub więcej prawdopodobnych hipotez. $\mathrm{Z}$ jednej strony żadna teoria hominizacji nie może pominąc tego zagadnienia, $\mathrm{z}$ drugiej daleko jeszcze do jego rozwiązania i chyba słusznie pisze Overhage, że przekracza to możliwości jednej tylko dyscypliny naukowej ${ }^{86}$. Każda $z$ dotychczasowych teorii opiera się na jakimś założeniu, którego nie można sprawdzić przy pomocy empirycznych danych. Sama zaś logiczna konstrukcja teorii, wbrew temu co pisze Révész ${ }^{87}$, nie stanowi dowodu jej prawdziwości. Niewątpliwie jednak każda $\mathrm{z}$ nich zawiera jakąś cząstkę prawdy i przygotowywuje przez to przyszłe rozwiązanie.

Wydaje się przeto, że podejmowanie dyskusji z poszczególnymi poglądami autorów nie prowadzi do pożądanego celu, gdyż brak empirycznych kryteriów nie pozwala na rozstrzygnięcie pytania, która $\mathrm{z}$ postawionych hipotez jest prawdziwa. W zagadnieniu początków mowy ludzkiej i czasu jej powstania obracamy się ciągle w sferze możliwości i mniej lub więcej uzasadnionych przypuszczeń. Większe lub mniejsze prawdopodobieństwo poszczególnych teorii zależy od siły założeń, na których się opierają. Dlatego, zamiast analizy i krytyki poszczególnych teorii, należy raczej szukać takiej zasady dla naszych rozważań, która rzuciłaby nowe światło na problem początków mowy ludzkiej. Wydaje się, że taką zasadę stanowi teoria ewolucji zastosowana konsekwentnie do naszego problemu. $\mathrm{Z}$ zasad teorii ewolucji wynikają dwa ważne stwierdzenia. Ewolucja zakłada po pierwsze ciągłość rozwoju, po drugie nowość ewolucyjną, która pojawia się zazwyczaj jako próg podniesienia i przekształcenia w dotychczasowej linii rozwoju. Pamiętać przy tym należy, że wraz z pojawieniem się człowieka ewolucja przeszła $z$ fazy biernej, obejmującej naszych zwierzęcych przodków, w fazę czynną, czyli w ewolucję kierowaną pod pewnymi względami przez człowieka ${ }^{88}$. Z zasad tych wynika, że z jednej strony mowa ludzka stała w pewnej rozwojowej ciągłości z mową zwierzęcą, z drugiej musiała wnieść do niej coś zupełnie nowego, specyficznego tylko dla mowy ludzkiej.

W swej fazie biernej ewolucja przygotowała ruchowy aparat mowy, dźwiękowe elementy mowy oraz neuromotoryczną strukturę mózgu. Struktura mózgu ludzkiego, jako podstawowa biologia dla mowy, pozostała w zasadzie niezmienioną i tym tłumaczą autorzy wspólne gramatyczne i fonetyczne rusztowanie każdego języka ${ }^{89}$. Przy rozważaniu ciągłości ewolucyjnej mowy należy pamiętać, że nie wiemy, na jakim stopniu rozwoju stali nasi bezpośredni zwierzęcy przodkowie. Prawdopodobnie na wyższym, a w każdym razie nie na niższym, niż współczesne mał-

\footnotetext{
86 Art. cyt., 382, 397.

87 Dz. cyt., 175.

88 Zob. G. Heberer, Der Ursprung des Menschen ${ }^{3}$, Stuttgart 1972, 9.

89 Zob. Illies, Zoologie, 109-110; Luria, dz. cyt., 190; K u r c z, dz. cyt., 206.
} 
py człekokształtne. Dlatego sugestywną jest wyżej wspomniana myśl Schindewolfa, że już przed pojawieniem się człowieka mogły zaistnieć początki słów i abstrakcyjnego myślenia ${ }^{90}$.

Druga zasada ewolucji mówi o novum ewolucyjnym wniesionym na progu przerobienia i podniesienia tego, co było przygotowane w uprzedniej fazie rozwoju. Pytanie, co stanowi to novum ewolucyjne w dziedzinie mowy, dotyka istoty zagadnienia. Badacze dają różne odpowiedzi na to pytanie. P. Wezler pisze, że nowością mowy ludzkiej jest bogata treść porozumiewania się. Słowo staje się nosicielem znaczenia w o wiele wyższym rozumieniu, niż ma to miejsce w dźwiękach zwierzęcych. Jeżeli mowę uważa się za: 1. przekaz wiadomości, 2. wyzwolenie reakcji u odbiorcy, 3. przedstawienie stosunków rzeczowych ujętych przez nadawcę, to trzeci stopień, biologicznie najmłodszy, stanowi według Wezlera nieprzekraczalną 'granicę, jaka dzieli człowieka od zwierzęcia. Biologowie uważają te trzy stopnie mowy za następujące po sobie stadia. Obwodowy aparat głosowy zwierząt byłby w stanie wyprodukować dźwięki mowy, gdyż jest to możliwe ze względu na rozwój ich mózgu, natomiast nie posiadają zdolności przekładu dźwięków na sekwencje słów i zdań ${ }^{91}$.

Badania ostatnich lat nad mową szympansów sugerują, że chyba nie na tym polega novum ewolucyjne mowy wniesione przez człowieka. Ploog zwraca uwagę, że wspólnym między ludzką i zwierzęcą awerbalną komunikacją jest rozpowszechniony $\mathrm{w}$ świecie zwierzęcym proces semantyzacji i to może uchodzić za zasadnicze uprzednie założenie dla wszelkiego sposobu porozumiewania się. Wzrost bogactwa używanych środków dla wymiany informacji idzie $w$ parze $z$ tworzeniem społeczeństw. Procesowi temu u Prymatów towarzyszy proces indywidualizacji, ponieważ każdy członek grupy posiada pewien zakres wolności działania ${ }^{92}$. Proces indywidualizacji można nazwać przedstadium wolności i równocześnie, jeżeli idzie o naszych bezpośrednich przodków, przedstadium czynnej fazy ewolucji, charakterystycznej dla człowieka.

Proces semantyzacji, o którym mówi Ploog, odsłania tę naturę mowy, którą przypisywano dotychczas tylko człowiekowi. U Naczelnych bowiem obserwujemy przedstadium trzeciego stopnia mowy, na którym przekaz staje się nie tylko wyrażeniem wiadomości, lecz także stanowi przekaz stosunków rzeczowych, istniejących niezależnie od nadawcy i odbiorcy. Doświadczenia z szympansami Sarah i Lanq wykazują, że dochodzą one do poznania i wyrażenia stosunków równości, podobieństwa, prawej i lewej strony, twierdzenia i przeczenia. Doświadczenia nad makakami na wyspie Kojimo w Japonii okazały, że potrafią one nie tylko się uczyć,

90 Art. cyt., 289.

91 Menschliches Leben in der Sicht des Physiologen, w: Neue Anthropologie, Bd, II, Biologische Anthropologie, Zweiter Teil, Stuttgart 1972, 372.

92 Art. cyt., 169-170. 
lecz także przekazywać swe indywidualne doświadczenia innym członkom grupy i następnym pokoleniom, co stanowi przedstadium tradycji, rezerwowanej dotychczas tylko dla człowieka. Dodajmy, że Sarah $i$ Lana potrafią budować zdania, a ta ostatnia pyta o nazwę przedmiotu, którą stanowi znak arbitralny. Nie można przeto odmówić ich awerbalnym środkom komunikowania początków semantyzacji i ujmowania stosunków rzeczowych. Jak daleko sięgają te zdolności, nie wiemy. Wynika z nich jedno, dodaje Ploog, że doświadczenia te otworzyły nieoczekiwane perspektywy, przesunęły granicę między mową ludzką i zwierzęca, oraz postawiły nowe pytania antropologom, psychologom $i$ lingwistom ${ }^{93}$.

Sama nauka awerbalnej mowy przybiera u Sarah i Lany formy ludzkie, ponieważ wyniki osiąga się mniej przez podawanie nagrody w postaci owoców, a więcej przez wytworzenie stosunku partnerstwa między szympansami i człowiekiem. A to jesṫ coś więcej, niż instynktowna potrzeba wyrażania i zaspokajania swych biologicznych potrzeb. Dlatego podkreśla się dzisiaj, że i w duchowo-psychicznej stronie zaczyna stawać się nieostrą granica między zwierzęciem i człowiekiem. Doświadczenia te bowiem prowadzą do wyższej oceny życia psychicznego zwierząt, niż to czyniono dawniej. Okazało się, pisze Overhage, że wewnętrzność Prymatów jest w wielu punktach podobna do ludzkiej ${ }^{94}$.

Dochodzimy przeto do wniosku, że novum ewolucyjne mowy ludzkiej nie polega na rozwoju aparatu fonacyjnego. Nie polega na samym ilościowym rozwoju mózgu. Nie polega na samej artykulacji dźwięków, gdyż tę zdolność posiadają także zwierzęta. Nie polega na zdolności przekazywania indywidualnych doświadczeń, ani na wyrażaniu swych stanów wewnętrznych, gdyż to wszystko spotykamy i u zwierząt. Nowość ewolucyjna nie polega na samej symbolizacji, gdyż Sarah i Lana potrafią używać arbitralnych znaków i budować zdania. Nie polega na przekazywaniu stosunków rzeczowych, ponieważ początki tej zdolności obserwujemy u Sarah i Lany. Nie polega na przejściu z zawarunkowania genetycznego $\mathrm{w}$ sferę wolności, ponieważ przedstadia tejże obserwujemy $\mathrm{w}$ procesie uczenia się szympansów. Wszystkie wymienione cechy same nie wskazują jeszcze na zasadniczą różnicę między mową ludzką i zwierzęcą.

Pozostaje przeto dalej pytanie, na czym polega nowość ewolucyjna w rozwoju mowy, czyli co stanowi specyficzną cechę, właściwą wyłącznie mowie ludzkiej. Wydaje się, że tym novum ewolucyjnym powstałym na progu przejścia z mowy zwierzęcej do ludzkiej jest cecha trans cendencji mowy ludzkiej. Transcendencja mowy ludzkiej wyraża się $\mathrm{w}$ oderwaniu czy przekroczeniu przez ludzką mowę artykułowaną sfery ikonicznej, tj. stałego związania obrazu i dźwięku z przedmiotem, a wej-

93 Art. cyt., 158.

94 Art. cyt., 395-396. 
ście $\mathrm{w}$ dziedzinę wolnych alternatyw, dziedzinę dowolnych skojarzeń ${ }^{95}$. Podejście od tej strony do zagadnienia specyfiki mowy ludzkiej rzuca nowe światło na omawiane zagadnienie.

Stwierdzenie to domaga się jednak dalszych wyjaśnień. I. Kurcz rozróżnia pierwszą i drugą artykulację. Pierwsza przebiega na poziomie zdania i polega na łączeniu wyrazów, ściślej morfemów (najmniejsza jednostka znacząca) w całość, którą jest zdanie. Morfemy można rozłożyć na poszczególne elementy, czyli na poszczególne dźwięki tzw. fonemy (w piśmie odpowiadają im grafemy), które same w sobie nie posiadają znaczenia. Dowolne łączenie ich i nadawanie im znaczeń stanowi drugą artykulację na poziomie fonologicznym ${ }^{96}$. Overhage nawiązuje $\mathrm{w}$ tym względzie bezpośrednio do naszego zagadnienia pisząc, że mowa ludzka jest ukształtowana według tej zasady, iż słowa, jako najmniejsze nosiciele znaczenia, składają się z możliwie małej liczby elementów składo.* wych (fonemy), np. dźwięków czy liter. W·rzeczywistości żadna z liter nie znaczy sama w sobie nic, natomiast ich kombinacja umożliwia wszystko ${ }^{97}$. Drugą artykulację możemy pojmować jako przejście ze sfery ikonicznej w sferę wolności, czyli wyróżnienia i dowolnego łączenia fonemów i to uważam za wyraz transcendencji mowy ludzkiej. Jak dotąd, zwierzęta nie osiągnęły tej cechy ani na poziomie fonemów, ani na poziomie grafemów. Wypowiedzi licznych autorów uważających słowo za dane tylko człowiekowi należy uściślić $w$ tym sensie, że nie morfemy (słowa) lecz fonemy są dane tylko człowiekowi i dowolne ich łączenie stanowi o transcendencji mowy ludzkiej.

$\mathrm{Z}$ kolei powstaje pytanie, co jest przyczyną transcendencji mowy ludzkiej. Pytając o przyczynę, szukamy nie granicy, lecz zasady, która dzieli nie tylko mowę ludzką od zwierzęcej, lecz także psychizm ludzki od zwierzęcego. Źródłem i przyczyną transcendencji mowy ludzkiej jest duchowa strona człowieka. L. Weisgerber upatruje duchową stronę mowy $\mathrm{w}$ tym, co w zjawisku mowy jest ponadzmysłowe i co ukazuje się jako kształtująca siła ${ }^{98}$, co nazywamy po prostu duchem ludzkim. Przez wyniesienie psychizmu zmysłowego zwierzęcego przodka na poziom psychizmu duchowego u człowieka został przekroczony poziom istnienis i działania materialnego, a otworzył się świat duchowy, którego najpełniejszym wyrazem stało się myślenie i wolność. Transcendencja ta spłynęła także na mowę i ona stanowi o barierze między mową ludzką i zwierzęcą. Zasada transcendencji pozostaje niezmienioną, niezależnie od tego,

9s Pojęcie tej sfery wprowadził amerykański antropolog R. L. Holloway (1969). Zob. K. Jettmar, Die anthropologische Aussage der Ethnologie, w: Neue Anthropologie, Bd IV, Kulturanthropologie, Stuttgart 1973, 81-82.

${ }_{9 i}$ Dz. cyt., 100.

$: 7$ Art. cyt., 385.

9 Art. cyt., $180-181$. 
jak daleko będziemy przesuwać granicę pomiędzy mową zwierzęcą i ludzką. Granice zresztą mogą być przesuwane dalej, gdyż szympanse mogą prawdopodobnie uzyskać jeszcze większe osiągnięcia niż dotychczas. Niezależnie od tego twórcza wolność ducha ludzkiego będzie stanowić zawsze nieusuwalną podstawę różnicy, ponieważ zwierzęta mogłyby się otworzyć na tę transcendencję tylko przez hominizację.

Pytając przeto o początki mowy ludzkiej, pytamy o moment przekroczenia, transcendencji ikonicznej sfery, o moment zaistnienia swobodnych kojarzeń i nadawania dowolnych znaczeń poszczególnym dźwiękom. Transcendencja mowy ludzkiej wyraża się w drugiej artykulacji. Inne pytania dotyczące początków mowy ludzkiej pozostają dalej zagadką trudną do rozwiązania ze względu na brak jakichkolwiek empirycznych danych. Przyczyną powstania mowy ludzkiej jest duch ludzki i dlatego wolno przypuszczać, że początki hominizacji i mowy są bardzo zbliżone do siebie w czasie. Fundamenty pod mowę ludzką mogły być położone już w pierwszej rodzinie ludzkiej, ze względu na szczególną wewnętrzną więź łączącą członków ludzkiej rodziny.

\section{DAS PROBLEM DES URSPRUNGS DER MENSCHLICHEN SPRACHE}

\section{Z U S A M M E N F A S S U N G}

Die wissenschaftliche Untersuchung der Anfänge der meschlichen Sprache und ihrer Entstehungszeit stellt ein schwieriges und zusammengesetztes Problem aus diesem Grund dar, weil es gänzlich an empirischen Daten fehlt. Auf der Suche nach der Lösung dieses Problems stellen die Autoren mehr oder weniger wahrscheinliche Hypothesen oder einfache Vermutungen. In den Untersuchungen gehen sie von zwei verschiedenen Standpunkten aus. Die einen nehmen die evolutive Kontinuität der tierischen und menschlichen Sprache an, die enderen lehnen sie ab. Es scheint, dass die Stellungnahme der ersten richtiger ist, weil sie Vorteile in der Lösung des Problems bietet. In diesem Artikel stellt der Verfasser einige Theorien und Manche Beiträge der Autoren dar zur Lösung der Frage nach den Anfängen und der Entstehungszeit der menschlichen Sprache.

In der Schlussfolgerung legt der Verfasser einen Versuch der Lösung dieses Problems vor in Anlehnung an die zwei Grundsätze der Evolutionstheorie. Der erste Grundsatz setzt die Kontinuität der tierischen und menschlichen Sprache voraus. Aus dieser Stellungnahme folgt, dass die ersten Menschen die ganze sprachliche Ausstattung von ihren tierischen Vorfahren übergenommen haben. Von dem zweiten Grundsatz ausgehend, sieht der Verfasser das novum evolutivum in der Transzendenz der menschlichen Sprache. Diese Transzendenz kommt zum Ausdruck nicht in der Bildung der Wörter, nicht in der Artikulation der Sprache, sondern in der freien Bindung und in dem schöpferischen Geben neuer Bedeutungen den Phonemen. Die Ursache dieser Transzendenz sieht der Verfasser in dem Schaffen des schöpferischen und freien menschlichen Geistes. 